\title{
The Effect Of The Flipped Classroom On Nursing Students' Learning And Motivation Outcomes In Health Education
}

\author{
Mouna Hannaoui ${ }^{1,2^{*}}$,Salmane Bourkeddi ${ }^{3,4}$, El Hassan El Hassouny ${ }^{1,2}$, María Luisa Grande- \\ Gascón ${ }^{5}$, Rajae Zerhane1 ${ }^{1}$, Mourad Madrane'. \\ ${ }^{1 *}$ Interdisciplinary Laboratory of Research in Pedagogical Engineering (LIRIP), Abdelmalek Essaadi University, \\ Higher Teacher Training School, Tetouan, Morocco. \\ ${ }^{2}$ Higher Institute of Nursing Professions and Health Techniques, Tetouan, Morocco. \\ ${ }^{3}$ University of Poitiers, France \\ ${ }^{4}$ Ibn tofail University, Morocco. \\ ${ }^{5}$ Faculty of Health Sciences. University of Jaén. \\ Email: mouna.hannaoui@etu.uae.ac.ma \\ ORCID https://orcid.org/0000-0001-5945-8356
}

Article History: Received: 11 January 2021; Accepted: 27 February 2021; Published online: 5 April 2021

\begin{abstract}
As contemporary society evolves, the technological revolution increasingly requires higher education institutions to adopt innovative strategies instead of traditional teaching. Improving the training of health professions in innovative teaching strategies would help prepare future nurses for professionalization. Therefore, the flipped classroom is one of the active educational approaches that has been shown to be effective on nursing students' outcomes and motivation.

Our study, spread over two years from 2018 to 2020, is a quantitative experimental pilot study, which aims to examine the effect of the flipped classroom on nursing students' learning and motivation outcomes in health education of undergraduate nursing students of the 'Higher Institute of Nursing Professions and Health Techniques' (ISPITS).

We used two tests, knowledge test and motivation test. The control group consisted of 15 students against 17 students from the experimental group. The experiment lasted three months.

Our results showed a statistically highly significant $(p<0.0001)$ increase $(p<0.0001)$ in the grades and motivation levels of students in the experimental group. We point out that our experience coincided with the COVIC-19 pandemic which forced distance learning.

According to our results, The flipped classroom could be an effective way to enhance the learning of nursing students and improve their motivation for knowledge to teach health sciencess
\end{abstract}

Key Words: flipped classroom, effect, outcomes, motivation, students, nursing, health education, ISPITS.

\section{INTRODUCTION}

In today's ever-changing active society, the context of higher education cannot escape the upheaval caused by social pressure in terms of academic achievement and that exerted by the world of work which has become increasingly demanding in terms of skills (Suarta, 2017). To this end, the integration of information and communication technologies (ICTs) in education has been required to adapt higher education institutions to the digital society (Hu et al., 2018).

Along the same line, these institutions are being led to adopt innovative strategies instead of lecturing, which is the most widespread practice in higher education (Mikkelsen, 2015). Since technology-related factors influence the scientific learning of learners (Jayawardena, van Kraayenoord \& Carroll, 2020), In this sense, studies have revealed that active teaching strategies increase the learning process and outcomes of learners (Freeman et al, 2014.; Y1lmaz, 2016), as well as their motivations (Davies, Dean \& Ball, 2013; Yilmaz, 2017). Indeed, there are many teaching strategies that have incorporated ICT into teaching practices (Jayawardena, van Kraayenoord \& Carroll 2020). One of these new active pedagogy strategies is the flipped classroom (Lebrun, Gilson \& Goffinet, 2016; Hu et al., 2018; Yilmaz, 2017). The use of this approach dates back several centuries (Dumont \& Berthiaume, 2016). However, it was named for the first time in 2007, following the experience of two chemistry teachers at Woodland Park High School in Colorado, Jonathan Bergmann and Aaron Sams, who used video capsules in their teaching practice to allow absent or sick students to follow their classes (Lebrun \& Lecoq, 2016). This approach involves moving course content out of the classroom and having students watch it at home in the form of video lectures to free up classroom time for exercises, projects or discussions (Educause, 2012; Lebrun, Gilson \& Goffinet, 2016; Mikkelsen,2015). However, 
creating instructional videos requires a lot of energy on the part of the teacher (Enfield, 2013; Lebrun \& Lecoq, 2016; Mason, Shuman \& Cook, 2013; Sales, 2013; Sherbino, 2013). For this reason, researchers suggest flipping only part of the course in order to lighten the load on the teacher and students (Dumont \& Berthiaume, 2016).

Also, in this pedagogical approach, the teacher is no longer necessarily the primary source of information. He or she becomes a session leader and facilitator, in order to help his or her students apply and integrate the knowledge to be taught (Tune, Sturek \& Basile, 2013). Mikkelsen (2015) argued that in a flipped classroom, students can learn at their own pace, when and where it suits them.

In this respect, the literature has reported improved students' learning outcomes in comparison to courses taught in the flipped classroom (Wang, 2017; Hung, Aşıksoy \& Özdaml1, 2016; Deslauriers, Schelew and Wieman ,2011; Presti, 2016).

Also, flipped classroom encourages students to acquire cognitive skills such as pre-lesson knowledge acquisition, while focusing on higher level cognitive skills such as application, analysis, synthesis and evaluation with paired learning during class $(\mathrm{Hu}, 2018)$. This may explain the increased motivation of students to acquire knowledge and skills (Prince, 2004). Since one of the underlying mechanisms contributing to increased performance in inverted classrooms is intrinsic learner motivation (Persky \& McLaughlin, 2017; Sergis, Sampson \& Pelliccione, 2018),

Thus, because of the benefits of this approach, flipped classroom pedagogy has attracted the attention of educators and has been widely implemented and studied in many disciplines, including nursing (Betihavas et al., 2016; Galway et al., 2014; Hu et al., 2018; Mikkelsen, 2015; Lichvar et al., 2016; Liebert et al., 2016; Njie-Carr et al., 2017; Presti,2016;).

However, the implementation of the flipped classroom in higher nursing education remains controversial (Evans et al., 2019; Hu et al., 2018; Presti et al., 2016; Tan, Yue \& Fu, 2017; Yacout \& Shosha, 2016). Since, some studies have shown that the flipped classroom model in nursing education has some advantages over traditional classroom learning in terms of improved students' outcomes, grades and satisfaction (Critz \& Knight, 2013; Geist et al., 2015; Yacout \& Shosha, 2016). Conversely, some researchers disagree with these findings (Hanson, 2016; Harrington et al., 2015; Simpson \& Richards, 2015; TIAN, JIN \& LIU, 2015; Yacout \& Shosha, 2016).

Among the reasons for the difference in results was the variety of teaching knowledge to which the flipped classroom was applied. For example, in the field of health professional education, which considers itself a cross-cutting teaching skill, an international meta-analysis showed a significant improvement in student's performance after attending flipped classrooms compared to participation in traditional education (Hew \& Lo, 2018). These results lead us to question the effect of the application of this approach on other multidisciplinary and transversal teaching skills such as health education.

In Morocco, to our knowledge, no study has experimented with the effect of the flipped classroom in nursing sciences, and more specifically in relation to health education. However, knowledge to be taught that has an interdisciplinary character should produce graduates with basic health science skills (Kim, 2019). In addition, a very recent study has been done on the analysis of educational descriptions of the bachelor's degree programme of the 'Higher Institute of Nursing Professions and Health Techniques' (ISPITS). The results found, referred to the inadequacy of the overall hourly volume of training in the bachelor's degree class of the ISPITS, since it represents only $52 \%$ of the hourly volume dictated by the Bologna process (Barich, Chamkal and Rezzouk, 2019). This study was added to another one to find that programmes are not designed according to the competency-based approach (Abouzaj, 2019; Barich, Chamkal and Rezzouk, 2019).

Therefore, in order to overcome these shortcomings in terms of hourly volume, to be in line with the competencybased approach and since different educational systems or cultural backgrounds may influence the effectiveness of the flipped classroom method (Frambach et al., 2012), and referring to the advantages and suggestions mentioned above, we considered it useful to experiment for the first time with flipped classroom teaching on "health education" for the benefit of undergraduate students in the nursing education. Our experimentation is determine the effect of the flipped classroom on students' outcomes and motivation.

We opted for this approach, since theoretical knowledge scores are relatively objective and reliable for determining the effectiveness of the flipped classroom compared to other approaches (Hu et al., 2018). Motivation testing was included because it is necessary for students' engagement in the learning process (Sampson \& colleagues, 2018). Pelliccione, 2018). We have therefore chosen to apply this approach to health education because of its cross-cutting and multidisciplinary nature, which aims to develop fundamental skills in future nurses (Kim, 2019).

The objective of this work is to examine the effect of teaching "the pedagogical sequences of courses related to health education in health programmes" in flipped classroom, on the results and degree of motivation of students in the nursing stream of the 'Higher Institute of Nursing Professions and Health Techniques' (ISPITS) in Tetouan, Morocco. Our two research questions are :

$\checkmark$ Will teaching health education using flipped classrooms have an effect on students' outcomes? 
Mouna Hannaoui ${ }^{1,2^{*}}$,Salmane Bourkeddi ${ }^{3,4}$, El Hassan El Hassouny ${ }^{1,2}$, María Luisa Grande-Gascón ${ }^{5}$, Rajae Zerhane ${ }^{1}$, Mourad Madrane ${ }^{1}$.

$\checkmark$ Will the teaching of health education using flipped classrooms have an effect on learners' motivation? As a result, the two hypotheses are formulated as follows:

H0: "The use of flipped classroom has no effect on the outcomes of nursing students in health education".

H01: "The use of the flipped classroom has an effect on the outcomes of nursing students in health education".

H1: "The use of the flipped classroom has no effect on the motivation of nursing students in health education.

H11: "The use of the flipped classroom has an effect on the motivation of nursing students in health education.

\section{METHODOLOGY}

The starting point for our approach was the hypotheses shared by the researchers that the use of the two tests "Health Education Knowledge Test" and "Health Education Learning Motivation Questionnaire" are necessary to examine the effect of the flipped classroom on students' knowledge and motivation results for teaching health education.

\subsection{Type of study}

It is a correlational experimental prospective quantitative study that ran from the academic year of 2018/2019 to the academic year of 2019/2020.

\subsection{Participants}

A total of 32 undergraduate nursing students from ISPITS in Tetouan, receiving courses from the health programs, were the participants in this study. 15 students made up the class of the control group in 2018 and 17 students made up the class of the experimental group in 2019. The inclusion criterion of these cohorts (classes) was due to the teaching of courses that included pedagogical sequences on health education.

\subsection{Online learning platform}

In this study, the ISPITS Moodle platform was selected as a learning platform for pre- and post-classroom learning. Moodle is an ISPITS educational platform designed for teachers who want to flipp their classes. It allows to download pre-existing course materials in different formats from several sources (You Tube, Personal Computer...) and share them with students who can benefit from immediate feedback from the teacher.

In order to allow students to familiarize themselves with Moodle, a training session was organized to explain the functioning of this platform to them. The training took place a few days before the beginning of the experiment.

\subsection{Research design}

The research design is presented in Table 1. During the year 2018/2019, the "Health Education Knowledge Test" was administered to the control group before and after the course taught by traditional methods. In 2019/2020 the same test was administered to the experimental group. A second "motivation test" was sent to the same group. These two tests were sent before and after the experiment (flipped classroom teaching). We then proceeded to compare the results obtained by these students, using recognized statistical methods such as the means and the t-student test.

Table 1. Research Design

\begin{tabular}{|l|l|l|l|}
\hline Group & Pre-test & Application & Post-test \\
\hline $\begin{array}{l}\text { Experimental Group } \\
(17 \text { students })\end{array}$ & $\begin{array}{l}\text { - Knowledge test of health } \\
\text { education. } \\
\text {-Motivation questionnaire. }\end{array}$ & Flipped classroom & $\begin{array}{l}\text {-Knowledge test of health } \\
\text { education. } \\
\text {-motivation questionnaire. }\end{array}$ \\
\hline $\begin{array}{l}\text { Control Group } \\
(15 \text { students })\end{array}$ & $\begin{array}{l}\text {-Knowledge test of health } \\
\text { education. }\end{array}$ & Traditional method & $\begin{array}{l}\text {-Knowledge test of health } \\
\text { education }\end{array}$ \\
\hline
\end{tabular}

\section{5 flipped classroom model inspired by Santikarn and Wichadee (2018)}

Scripting plays an important role in the traditional and flipped classroom, so sequencing and progression should be carefully considered (Jovanovic et al., 2019).

To flipp the class, this study adopted the model presented in Figure 1, a model proposed in 2018 by Santikarn and Wichadee, adapted from that proposed by Estes et al (2014). The model consists of three stages, the first and last stage taking place outside the classroom, while the second stage takes place in the classroom.

This model has been adapted according to the nature of the knowledge to be taught "health education" and the didactic tools adopted. 


\section{Pre-class stage (On the Moodle platform)}

Sending a tutorial on how to use the Moodle platform.

\section{Exhibition of the} Pedagogical Scripting of the course on the Moodle platform.

Sending of the course materials in advance to students (SOOCs, file of the whole course, articles on health education...)

\begin{tabular}{|l}
$\checkmark \quad$ Etep in class (In the classroom) \\
$\quad$ contract. \\
$\checkmark \quad$ Explanation of the approach of \\
the flipped classroom. \\
$\checkmark \quad$ Consensus on the sequences of \\
the course that will be approached \\
in the classroom and those that \\
will be approached in the flipped \\
classroom by E-learning \\
(asynchronous and synchronous). \\
$\checkmark \quad \begin{array}{l}\text { Pre-testing of knowledge in } \\
\text { relation to health education } \\
\text { (Diagnostic evaluation during the } \\
\text { first session). }\end{array}$ \\
$\checkmark \quad \begin{array}{l}\text { Pre-test of students' motivation } \\
\text { (in the first session). } \\
\checkmark\end{array}$ \\
Learning by problem situations, \\
application exercises, \\
brainstorming discussions, \\
question-answer sessions, etc. \\
(during all face-to-face sessions).
\end{tabular}

Post-class stage (on Moodle platform)

$\checkmark$ Consultation of the teaching aids of each pedagogical sequence.

$\checkmark$ Productions elaborated by students on each sequence (formative evaluations).

$\checkmark$ Audiovisual discussions (between teacher and students).

$\checkmark$ Adjustments of the productions (made by students) taking into consideration the remarks made by the teacher and the students.

$\checkmark \quad$ Re-exposure of individual works.

$\checkmark$ Posttest of motivation towards health education.

$\checkmark$ Posttest of knowledge about health education (summative evaluation)

Figure 1: Course scenario design based on Santikarn and Wichadee's flipped classroom model (Santikarn and Wichadee, 2018) and adjusted according to the approach taken.

\subsection{Procedure}

This study was carried out over a two-year period starting in the 2018/2019 academic year. The control group was taught the pedagogical sequences on health education according to the traditional method for 3 months during the 2018/2019 academic year, the experimental group received the same pedagogical sequences using the flipped classroom for 3 months during the 2019/2020 year, the courses were taught by the researcher who has a permanent teaching profile at ISPITS.

For the experimental group: Before starting the experiment, the researchers prepared the pedagogical scenario.

- Before the course: The student consults the didactic materials of the knowledge to be taught at any time, takes notes and prepares questions on subjects she/he does not understand.

During the course: The teaching/learning activities in the classroom (face-to-face) are carried out, such as learning by problem situations, application exercises, brainstorming discussions, question and answer sessions, etc.

-After the course: Focus group discussions on the platform, feedback, debates on the students' productions and formative and summative evaluations take place.

During the $1^{\text {st }}$ session of the course and during the elaboration of the learning agreement, the teacher explained the flipped classroom approach that will be adopted during the teaching of the pedagogical sequences on health education to the whole class, and then to help his students to appropriate this approach, the teacher sent the tutorial on how to use the ISPITS Moodle platform and the course materials to the students and encouraged them to consult the materials at home in order to learn at their own pace, and led the discussion and answered questions and problems expressed by the students via the platform. In class during the $2^{\text {nd }}$ session, the teacher facilitated and managed the session by encouraging all the students to express their opinions on the experience (needs, difficulties, questions...) by brainstorming. He also stimulated the students to interact and participate in the resolution of problem situations on 
Mouna Hannaoui ${ }^{1,2 *}$, Salmane Bourkeddi ${ }^{3,4}$, El Hassan El Hassouny ${ }^{1,2}$, María Luisa Grande-Gascón ${ }^{5}$, Rajae Zerhane ${ }^{1}$, Mourad Madrane ${ }^{1}$.

themes related to the course. In groups, the students elaborated productions which were then sent via platform and initiated the debate between the students. At the end, the teacher adjusted the productions by giving constructive remarks to each production and the students benefited from the remarks. In the classroom, the students participate actively in the lectures by taking part in discussions during the lessons. The control group received the course in the traditional face-to-face manner.

\subsubsection{Health Education Knowledge Test}

In order to identify the effect of the flipped classroom approach on students' success, a "Health Education Knowledge Test" consisting of 20 multiple-choice questions (inspired by the Ministry of Health's ISPITS access competitions) was prepared by the researchers and used as a diagnostic (pre-test) and summative (post-test) assessment.

-Pre-test: The "Health Education Knowledge Test" was used as a pre-test to determine the knowledge levels and prerequisites of the groups (control and experimental).

- post-test: 12 weeks later, in order to identify the level of advancement of the students in both groups with respect to the taught knowledge of health education, a post-test was applied to the students in both groups (control and experimental group).

\subsubsection{Motivation test}

In order to identify the effect of flipped classroom instruction on students' motivation, a Motivation Questionnaire developed by Glynn, Taasoobshirazi and Brickman (2009) was used and adapted according to the context of the study and the knowledge to be taught. This questionnaire consists of 24 questions and was used as both a pre-test and posttest for the experimental group during the study.

\subsubsection{The collection and statistical analysis of data}

A health education knowledge test and a motivational questionnaire were used as data collection tools. Basic variables were calculated using descriptive statistics, including arithmetic means and standard deviation tests. The violation of the normality hypothesis was revealed by the Shapiro-Wilk test, the Cronbach alpha test approved the reliability of the test (Yener, GÜLAÇTI and KANDEMIR, 2006). (See Table 2). Therefore, a non-parametric test was performed. The comparison of the variables was done by the T student test. All statistical analyses were performed using SPSS V 23 with a significance set at $5 \%$.

Table 2 Reliability Statistics

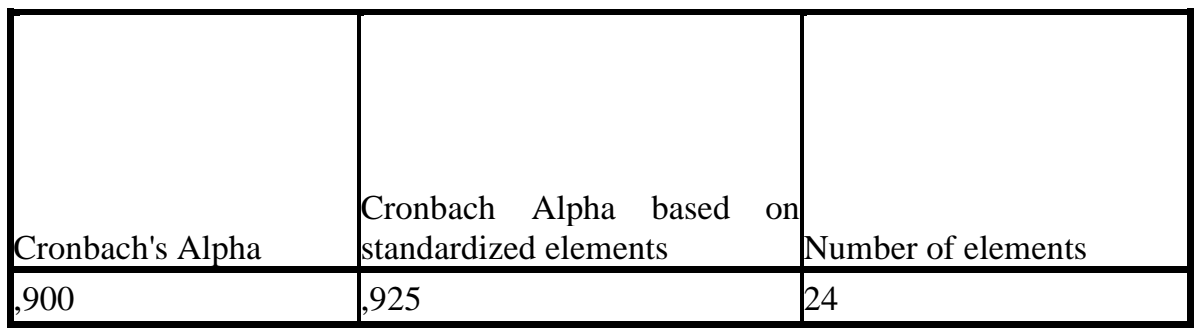

\section{RESULTS}

In this section, the results of the data analysis are presented below.

\subsection{Effect of the applied method on Students' results}

The "Health Education Knowledge Test" was used as a post-test to determine whether there was a significant difference in students' results. The results are presented in Table 1.

Table 1. Independent T-student test of the pre-test and post-test of the students' "Knowledge Test in Health Education".

\begin{tabular}{|c|c|c|c|c|c|c|c|c|c|}
\hline $\begin{array}{l}\text { Standard } \\
\text { deviation }\end{array}$ & $\begin{array}{l}\text { The } \\
\text { mean } \\
\text { scores } \\
\text { of the } \\
\text { control } \\
\text { group }\end{array}$ & $\begin{array}{l}\text { The mean score } \\
\text { of the } \\
\text { Experimental } \\
\text { group }\end{array}$ & $\begin{array}{l}\text { Difference } \\
\text { between } \\
\text { means }\end{array}$ & $\begin{array}{l}\text { Standard } \\
\text { Error } \\
\text { Of the } \\
\text { mean }\end{array}$ & $\begin{array}{l}\text { Confid } \\
\text { interva } \\
\text { of the }\end{array}$ & $\begin{array}{l}\text { ce } \\
\text { at } 95 \% \\
\text { ference }\end{array}$ & $\begin{array}{l}\mathrm{T} \text { - } \\
\text { Student }\end{array}$ & $\begin{array}{l}\text { Df } \\
=(15+17)-2\end{array}$ & P-value \\
\hline \multirow[t]{2}{*}{0,6682} & \multirow[t]{2}{*}{15,32} & \multirow[t]{2}{*}{17,71} & \multirow[t]{2}{*}{2,389} & \multirow[t]{2}{*}{0,3074} & lower & upper & \multirow[b]{2}{*}{7,773} & \multirow[t]{2}{*}{30} & \multirow[t]{2}{*}{$<0,0001$} \\
\hline & & & & & 1,761 & 3,017 & & & \\
\hline
\end{tabular}


The results obtained show that the mean scores of the students in the experimental group were significantly higher than those of the control group with a difference on the order of 2.389. To test whether this difference is positively significant and large enough to reject the null hypothesis, we used the "T-student" test (Zimmerman, 1987).

According to Table 1, "t-student" has a value of 7.773, which is much higher than 1.76 and the p-value is less than 0.0001. Therefore, we reject the H0 hypothesis and accept the H1 hypothesis: "the use of the flipped classroom has an effect on nursing students' health education outcomes" (Zimmerman, 1987). Thus, we find that teaching "health education" using the flipped classroom approach has a more positive effect on students' outcomes compared to teaching the course using traditional methods.

\subsection{Effect of the applied method on students' motivation}

The results of the motivational questionnaire distributed to students before and after the teaching of "health education" by flipped classroom are presented in Table 2 .

Table 2. Pre- and post-test dependent t-Student test of the students' motivation questionnaire.

\begin{tabular}{|l|l|l|l|l|l|l|l|}
\hline R2 & $\begin{array}{l}\text { Standard } \\
\text { Error } \\
\text { Of the mean }\end{array}$ & $\begin{array}{l}\text { Standard } \\
\text { deviation }\end{array}$ & $\begin{array}{l}\text { Difference } \\
\text { between } \\
\text { means }\end{array}$ & $\begin{array}{l}\text { Confidence interval at } \\
\text { 95\% of the difference }\end{array}$ & $\begin{array}{l}\text { T- } \\
\text { Student }\end{array}$ & P-value \\
\hline 0,9810 & 0,05275 & 0,2584 & 1,819 & lower & upper & 34,48 & $<0,0001$ \\
\hline
\end{tabular}

According to Table 2 , the value $\mathrm{p}<0.0001$, i.e. less than 0.05 , this difference is very significant at $95 \%$. This allows us to reject hypothesis $\mathrm{H} 1$ and to accept hypothesis H11: "the use of the flipped classroom has an effect on the motivation of nursing students in health education".

This finding indicates that students' motivation for the knowledge being taught has increased with the flipped classroom approach. For the motivation questionnaire, the following five items showed the largest increase: For the item "The health education course I am learning is relevant to my life", the mean pre-test score was $\mathrm{X}=1.05$, while the mean post-test score was $X=3.17$. For the item "I use innovative learning strategies to learn health education well...", the mean pre-test score was $X=1$, while the mean post-test score increased to $X=3.05$. Similarly, for the item "Learning about health education will help me to find a suitable job (work integration)" the mean pre-test score was $X=1.76$, while the mean post-test score was determined as $X=3.58$. Similarly, for the item "I'm sure I can understand this course" the pre-test mean score was $\mathrm{X}=1.58$, while the post-test mean score was determined as $\mathrm{X}=$ 3.64 .

\section{Discussion}

This study was conducted to identify the effects of the flipped classroom on the learning outcomes and motivation of nursing students towards "health education". Regarding the results of the post-test questionnaire of "health education knowledge", we found a statistically very significant increase in students' achievement. In this regard, we can say that teaching the knowledge to teach "health education" through the flipped classroom approach has a more positive effect on the students' success. Our results are consistent with others internationally. Indeed, the literature suggests that a flipped classroom approach can improve learners' performance (Bhagat, Chang and Chang, 2016; Huang and Hong 2016; Schultz et al. 2014; Tan, Yue and Fu, 2017; Zhai et al., 2017; Zhu et al., 2019).

Several reasons could explain this increase in students' level of mastery of knowledge by flipped classroom. Among others, the use of the questionnaire (pre-test) at the beginning of the course might have helped students to remember the knowledge acquired before the course. Prior knowledge has long been considered an important factor influencing learning (Hailikari, Katajavuori \& Lindblom-Ylanne, 2008; Merrill, 2012). Therefore, stimulating recall of prior knowledge helps learners to better understand new information by connecting it to something they already know. Furthermore, retrieving information from memory makes the path to that information in memory stronger; therefore, it allows the information to be more easily retrieved by the learner at the next opportunity (Dirkx, Kester \& Kirschner, 2014).

On the other hand, our findings are probably due to the fact that flipped classroom instruction emphasizes individualized, learner-centered learning, allowing the learner to internalize new knowledge at his or her own learning 
pace, (Hu et al., 2018). Also, in this study, we have multiplied and varied the pedagogical materials sent by the Moodle platform (SOOC developed by the teacher; pedagogical sequences in video format, application exercises, courses in ppt format...) in order to allow each student to learn by the means that suits him or her (differentiated pedagogy), which may have contributed in part to our results.

Another reason that could have positively influenced the learners' results was the short duration of our research, which was spread over three months. Indeed, Clark (2015) recognized that a novelty effect could lead to short-term improvements in students' performance when new technologies were introduced.

However, our results are inconsistent with other research, which has found no significant difference in students' outcomes between teaching by flipped classroom and traditional approaches (Chen, 2016; Clark, 2015; DeSantis et al 2015; Kirvan, Rakes, \& Zamora, 2015; Zainuddin et al., 2019). This could be explained by the nature of the course adopted, which is characterized by its specificity of transversality, and it has been found in the literature that the flipped classroom was more useful for this kind of theme (Fuentes Cabrera et al., 2020; Zamora-Polo et al., 2019).

As for the $2^{\text {nd }}$ important result of the study, we observed a very significant increase $(p<0.001)$ in the post-test of learners' motivation towards teaching health education in the flipped classroom. This finding indicates that learner motivation increased with this approach. This result supports the idea that student motivation levels increase under active learning conditions (Lecoq, Lebrun \& Kerpelt, 2017). It is also consistent with other results internationally (Baepler, Walker \& Driessen, 2014; Chua \& Lateef, 2014; Hu et al., 2018).

Indeed, several possible reasons could explain our finding. First, typically in nursing education institutes, courses are taught using a traditional approach, which negatively impacts students' engagement and attitude during the course. Also, students have little opportunity to communicate with their teachers after class, and the flipped classroom may leave students feeling that the teacher is more accessible (Tan, Yue \& Fu, 2017).

Another explanation that could interpret the positive effect of the flipped classroom on learners' motivation is the small sample size, since according to the literature, flipped pedagogy works best in classes with smaller students populations, rather than in large classes, since students' participation is much better in smaller classes where each student finds the opportunity to ask questions, present work, and discuss an idea (Hall \& DuFrene, 2016), and this is what was realized in our study. With regard to the five items of the motivation questionnaire that showed the strongest significance are respectively, "The health education course I am learning is relevant to my life", this significance aligns with the results of a study conducted by Kecskemety (2014), who reported that among the benefits of the flipped classroom is that it empowers students and helps them to develop lifelong learning skills. For the element 'I use innovative learning strategies to learn health education well', this recorded meaning could be due to the fact that the flipped classroom involves the student in his or her own learning process, unlike traditional teaching methods (Dumont $\&$ Berthiaume, 2016). For the element "Learning about health education will help me to find a suitable job (professional insertion)" we refer to the study by Lecoq's team (2017) who stated that in flipped pedagogy the learner is initiated to develop new skills such as those that enable him/her to manage projects etc... Similarly, for the element "I'm sure I can understand this course", is aligned with the findings of Prince (2004), who mentioned that the flipped classroom promotes students' motivation to acquire new knowledge. Also, this meaning is consistent with Kecskemety (2014), who suggested that the inverted class provides individualized instruction to address weaknesses or misconceptions of learners.

Finally, we point out that the realization of this work coincided with the COVID-19 pandemic, which forced the lockdown of students and imposed distance education through e-learning, so the flipped classroom allowed learners to learn without spatial and temporal constraints and to appropriate the new technologies (Vera, Fernández, \& Calatayud, 2016). And despite these crisis conditions, we have seen an increase in the level of knowledge and motivation of students in relation to the health education course taught using the flipped classroom.

\section{Conclusion}

This work, although it aims at exemple and not generalization, is a pilot study, which we intend to generalize on other ISPITS in the region and the kingdom in the coming years, on a larger number of students. The results of this work highlighted the positive effect of the flipped classroom on the undergraduate nursing students' grades at ISPITS in Tetouan, and their motivation to teach health education. Thus, our study adds to the literature to suggest that the flipped classroom could be an alternative to lecturing in nursing. Also, it could remedy the shortcomings in the number of hours of training for undergraduate education, since the content of the courses would be addressed at home and the class would be intended for application exercises, problem situations, etc.

As a result, other studies must be carried out to apply this approach to other knowledge to be taught and to other cohorts. To be able to compare the results and suggest other educational scenarios. 


\section{Study highlights}

The originality of this study lies in the fact that it is the first pilot study to our knowledge to study the effect of the flipped classroom on students' performance and motivation for health education for learners in the undergraduate nursing students. The flipped classroom approach was more effective than traditional courses in improving knowledge scores and learner motivation.

Theoretical knowledge scores are relatively objective and reliable in determining the effectiveness of flipped classrooms compared to other tests.

Also, and coincidentally this study was conducted during the COVID-19 pandemic, so the flipped classroom was used to inculcate the students in their learning process via platform while staying at home, but the interactivity, the debate, the mutual learning, the creation of problem situations... All this took place via platform with respect to the lockdown.

\section{Limitations}

Since this study was conducted on a small sample size, we suggest further studies on a larger sample size. We also suggest applying this approach to other knowledge to be taught.

\section{Study permit}

All students participated in the study with their approvals. Also we received permission and approval from the ISPITS management before starting the study.

\section{Références}

1. Abouzaj, S. (2019). Competency-Based Approach in Training Nurses and Midwives in Morocco Demystify to Better Use. Advances in Medical Education and Practice, 10, 1069.

2. Aşıksoy, G., \& Özdamlı, F. (2016). Flipped Classroom adapted to the ARCS Model of Motivation and applied to a Physics Course. Eurasia Journal of Mathematics, Science \& Technology Education, 12(6).

3. Baepler, P., Walker, J. D., \& Driessen, M. (2014). It's not about seat time: Blending, flipping, and efficiency in active learning classrooms. Computers \& Education, 78, 227-236.

4. -Barich, F., Chamkal, N., \& Rezzouk, B. (2019). La formation en soins infirmiers et techniques de santé dans le système licence-master-doctorat au Maroc: analyse des descriptifs de formation, étude analytique descriptive. Revue Francophone Internationale de Recherche Infirmière, 5(4), 100183.

5. -Bhagat, K. K., Chang, C. N., \& Chang, C. Y. (2016). The impact of the flipped classroom on mathematics concept learning in high school. Journal of Educational Technology \& Society, 19(3), 134-142.

6. -Chao, C. C. (2015). Rethinking transfer: Learning from call teacher education as consequential transition. Language Learning \& Technology, 19(1), 102-118.

7. Chen, L. L. (2016). Impacts of flipped classroom in high school health education. Journal of Educational Technology Systems, 44(4), 411-420.

8. Chua, J. S. M., \& Lateef, F. A. (2014). The flipped classroom: Viewpoints in Asian universities. Education in medicine journal, 6(4).

9. Clark, K. R. (2015). The effects of the flipped model of instruction on student engagement and performance in the secondary mathematics classroom. Journal of Educators Online, 12(1), 91-115.

10. Davies, R. S., Dean, D. L., \& Ball, N. (2013). Flipping the classroom and instructional technology integration in a college-level information systems spreadsheet course. Educational Technology Research and Development, 61(4), 563-580.

11. DeSantis, J., Van cuRen, R., Putsch, J., \& MetzgeR, J. (2015). Do students learn more from a flip? An exploration of the efficacy of flipped and traditional lessons. Journal of Interactive Learning Research, 26(1), 39-63.

12. Deslauriers, L., Schelew, E., \& Wieman, C. (2011). Improved learning in a large-enrollment physics class. science, 332(6031), 862-864.

13. Dirkx, K. J., Kester, L., \& Kirschner, P. A. (2014). The testing effect for learning principles and procedures from texts. The Journal of Educational Research, 107(5), 357-364.

14. Dumont, A., \& Berthiaume, D. (2016). La pédagogie inversée: Enseigner autrement dans le supérieur par la classe inversée. De Boeck Supérieur.

15. Educause, C. (2012). Things you should know about flipped classrooms.

16. -Estes, M. D., Ingram, R., \& Liu, J. C. (2014). A review of flipped classroom research, practice, and technologies. International HETL Review, 4(7). Repéré le 11 / 12 / 2019 à https://www.hetl.org/a-review-offlipped-classroom-research-practice-and-technologies/ 
Mouna Hannaoui ${ }^{1,2^{*}}$,Salmane Bourkeddi ${ }^{3,4}$, El Hassan El Hassouny ${ }^{1,2}$, María Luisa Grande-Gascón ${ }^{5}$, Rajae Zerhane ${ }^{1}$, Mourad Madrane ${ }^{1}$.

17. Evans, L., Bosch, M. L. V., Harrington, S., Schoofs, N., \& Coviak, C. (2019). Flipping the classroom in health care higher education: a systematic review. Nurse educator, 44(2), 74-78.

18. Frambach, J. M., Driessen, E. W., Chan, L. C., \& van der Vleuten, C. P. (2012). Rethinking the globalisation of problem-based learning: how culture challenges self-directed learning. Medical education, 46(8), 738-747.

19. Freeman, S., Eddy, S. L., McDonough, M., Smith, M. K., Okoroafor, N., Jordt, H., \& Wenderoth, M. P. (2014). Active learning increases student performance in science, engineering, and mathematics. Proceedings of the National Academy of Sciences, 111(23), 8410-8415.

20. Fuentes Cabrera, A., Parra-González, M. E., López Belmonte, J., \& Segura-Robles, A. (2020). Educational potentials of flipped learning in intercultural education as a transversal resource in adolescents. Religions, 11(1), 53.

21. Galway, L. P., Corbett, K. K., Takaro, T. K., Tairyan, K., \& Frank, E. (2014). A novel integration of online and flipped classroom instructional models in public health higher education. BMC medical education, 14(1), 181.

22. -Gagné, G., Sprenger-Charolles, L., Lazure, R., \& Ropé, F. (1989). Recherches en didactique et acquisition du français langue maternelle (1970-1984). Tome 1: Cadre conceptuel, thésaurus et lexique des mots-clés. Bruxelles, Paris, Montréal: De Boeck-Université, Éditions Universitaires, Institut National de la Recherche Pédagogique, consultée le, 15(04), 2011.

23. Geist, M. J., Larimore, D., Rawiszer, H., \& Al Sager, A. W. (2015). Flipped versus traditional instruction and achievement in a baccalaureate nursing pharmacology course. Nursing Education Perspectives, 36(2), 114-115.

24. Gilboy, M. B., Heinerichs, S., \& Pazzaglia, G. (2015). Enhancing student engagement using the flipped classroom. Journal of nutrition education and behavior, 47(1), 109-114.

25. Gingras, M. J. P., Stager, C. V., Raju, N. P., Gaulin, B. D., \& Greedan, J. E. (1997). Static critical behavior of the spin-freezing transition in the geometrically frustrated pyrochlore antiferromagnet $\mathrm{Y} 2$ Mo $2 \mathrm{O}$ 7. Physical review letters, 78(5), 947.

26. -Glynn, S. M., Taasoobshirazi, G., \& Brickman, P. (2009). Science motivation questionnaire: Construct validation with nonscience majors. Journal of Research in Science Teaching: The Official Journal of the National Association for Research in Science Teaching, 46(2), 127-146.

27. Hailikari, T., Katajavuori, N., \& Lindblom-Ylanne, S. (2008). The relevance of prior knowledge in learning and instructional design. American journal of pharmaceutical education, 72(5).

28. Hall, A. A., \& DuFrene, D. D. (2016). Best practices for launching a flipped classroom. Business and Professional Communication Quarterly, 79(2), 234-242.

29. Hanson, J. (2016). Surveying the experiences and perceptions of undergraduate nursing students of a flipped classroom approach to increase understanding of drug science and its application to clinical practice. Nurse education in practice, 16(1), 79-85.

30. Harmon, R. B., \& Hills, R. L. (2-015). Transforming psychiatric mental health nursing education with team based learning. Archives of psychiatric nursing, 29(6), 413-418.

31. Harrington, S. A., Bosch, M. V., Schoofs, N., Beel-Bates, C., \& Anderson, K. (2015). Quantitative outcomes for nursing students in a flipped classroom. Nursing Education Perspectives, 36(3), 179-181.

32. Hew, K. F., \& Lo, C. K. (2018). Flipped classroom improves student learning in health professions education: a meta-analysis. BMC medical education, 18(1), 38.

33. -Hu, R., Gao, H., Ye, Y., Ni, Z., Jiang, N., \& Jiang, X. (2018). Effectiveness of flipped classrooms in Chinese baccalaureate nursing education: A meta-analysis of randomized controlled trials. International Journal of nursing studies, 79, 94-103.

34. Huang, Y. N., \& Hong, Z. R. (2016). The effects of a flipped English classroom intervention on students' information and communication technology and English reading comprehension. Educational Technology Research and Development, 64(2), 175-193.

35. Hung, H. T. (2017). Clickers in the flipped classroom: bring your own device (BYOD) to promote student learning. Interactive Learning Environments, 25(8), 983-995.

36. Jayawardena, P. R., van Kraayenoord, C. E., \& Carroll, A. (2020). Factors that influence senior secondary school students' science learning. International Journal of Educational Research, 100, 101523. doi:10.1016/j.ijer.2019.101523

37. Jovanovic, J., Mirriahi, N., Gašević, D., Dawson, S., \& Pardo, A. (2019). Predictive power of regularity of pre-class activities in a flipped classroom. Computers \& Education, 134, 156-168.

38. Kecskemety, K. M., \& Morin, B. (2014). Student Perceptions of Inverted Classroom Benefits in a First-Year Engineer-ing Course. age, 24, 1. 
39. -Kim, H. N. (2019). A conceptual framework for interdisciplinary education in engineering and nursing health informatics.

40. Kirvan, R., Rakes, C. R., \& Zamora, R. (2015). Flipping an algebra classroom: analyzing, modeling, and solving systems of linear equations. Computers in the Schools, 32(3-4), 201-223.

41. Lecoq, J., Lebrun, M., \& Kerpelt, B. (2017). La classe à l'envers pour apprendre à l'endroit: guide pratique pour débuter en classe inversée.

42. Lichvar, A. B., Hedges, A., Benedict, N. J., \& Donihi, A. C. (2016). Combination of a flipped classroom format and a virtual patient case to enhance active learning in a required therapeutics course. American journal of pharmaceutical education, 80(10).

43. Liebert, C. A., Lin, D. T., Mazer, L. M., Bereknyei, S., \& Lau, J. N. (2016). Effectiveness of the surgery core clerkship flipped classroom: a prospective cohort trial. The American Journal of Surgery, 211(2), 451-457.

44. Merrill, M. D. (2012). Instructional transaction theory: An instructional design model based on knowledge objects. Instructional Design: International Perspectives: Volume I: Theory, Research, and Models: volume Ii: Solving Instructional Design Problems, 381.

45. -Mikkelsen, T. R. (2015). Nursing students' experiences, perceptions and behavior in a flipped-classroom anatomy and physiology course. Journal of Nursing Education and Practice, 5(10), 28-35.

46. -Njie-Carr, V. P., Ludeman, E., Lee, M. C., Dordunoo, D., Trocky, N. M., \& Jenkins, L. S. (2017). An integrative review of flipped classroom teaching models in nursing education. Journal of Professional Nursing, 33(2), 133-144.

47. Persky, A. M., \& McLaughlin, J. E. (2017). The flipped classroom-from theory to practice in health professional education. American journal of pharmaceutical education, 81(6).

48. Prince, M. (2004). Does active learning work? A review of the research. Journal of engineering education, 93(3), 223-231.

49. Presti, C. R. (2016). The flipped learning approach in nursing education: A literature review. Journal of Nursing Education, 55(5), 252-257.

50. Santikarn, B., \& Wichadee, S. (2018). Flipping the classroom for English language learners: A study of learning performance and perceptions. International Journal of Emerging Technologies in Learning (iJET), 13(09), 123-135.

51. Schultz, D., Duffield, S., Rasmussen, S.C. \& Wageman, J. (2014).Effects of the Flipped Classroom Model on Student Performance for Advanced Placement High School Chemistry Students.Journal of Chemical Education, 91(9), 1334-1339.

52. Simpson, V., \& Richards, E. (2015). Flipping the classroom to teach population health: Increasing the relevance. Nurse education in practice, 15(3), 162-167.

53. Sergis, S., Sampson, D. G., \& Pelliccione, L. (2018). Investigating the impact of Flipped Classroom on students' learning experiences: A Self-Determination Theory approach. Computers in Human Behavior, 78, 368-378.

54. Suarta, I. (2017). Revitalization of oral literature tradition of Balinese society based character values as deradicalism effort. International Journal of Social Sciences and Humanities, 1(3), 8-16.

55. -Tan, C., Yue, W. G., \& Fu, Y. (2017). Effectiveness of flipped classrooms in nursing education: Systematic review and meta-analysis. Chinese Nursing Research, 4(4), 192-200.

56. TIAN, Z. J., JIN, R. H., \& LIU, C. F. (2015). Application of flipped instruction in the course of Geriatric Nursing. Chinese Journal of Nursing Education, (5), 6.

57. Tune, J. D., Sturek, M., \& Basile, D. P. (2013). Flipped classroom model improves graduate student performance in cardiovascular, respiratory, and renal physiology. Advances in physiology education, 37(4), 316-320.

58. Vera, M. D. M. S., Fernández, I. M. S., \& Calatayud, V. G. (2016). FLIPPED-TIC: Una experiencia de Flipped Classroom con alumnos de Magisterio/FLIPPED-TIC: A Flipped Classroom experience with preservice teachers. Revista Latinoamericana de Tecnología Educativa-RELATEC, 15(3), 69-81.

59. Wang, F. H. (2017). An exploration of online behaviour engagement and achievement in flipped classroom supported by learning management system. Computers \& Education, 114, 79-91.

60. Yacout, D. A. E. S. A., \& Shosha, A. A. E. F. A. (2016). Nursing students' perceptions towards flipped classroom educational strategy. Journal of American Science, 12(2), 62-75.

61. -Yener, Ö. Z. E. N., GÜLAÇTI, F., \& KANDEMIR, M. (2006). The problem of validity and reliability in educational research. Erzincan Üniversitesi Eğitim Fakültesi Dergisi, 8(1), 69-89.

62. Yilmaz, R. (2016). Knowledge sharing behaviors in e-learning community: Exploring the role of academic self-efficacy and sense of community. Computers in Human Behavior, 63, 373-382. 
Mouna Hannaoui ${ }^{1,2^{*}}$, Salmane Bourkeddi ${ }^{3,4}$, El Hassan El Hassouny ${ }^{1,2}$, María Luisa Grande-Gascón ${ }^{5}$, Rajae Zerhane ${ }^{1}$, Mourad Madrane ${ }^{1}$.

63. -Yilmaz, R. (2017). Exploring the role of e-learning readiness on student satisfaction and motivation in flipped classroom. Computers in Human Behavior, 70, 251-260.

64. -Zainuddin, Z., Haruna, H., Li, X., Zhang, Y., \& Chu, S. K. W. (2019). A systematic review of flipped classroom empirical evidence from different fields: what are the gaps and future trends?. On the Horizon.

65. Zamora-Polo, F., Corrales-Serrano, M., Sánchez-Martín, J., \& Espejo-Antúnez, L. (2019). Nonscientific University Students Training in General Science Using an Active-Learning Merged Pedagogy: Gamification in a Flipped Classroom. Education Sciences, 9(4), 297.

66. -Zhai, X., Gu, J., Liu, H., Liang, J. C., \& Tsai, C. C. (2017). An experiential learning perspective on students' satisfaction model in a flipped classroom context. Journal of Educational Technology \& Society, 20(1), 198210.

67. -Zhu, L., Lian, Z., \& Engström, M. (2019). Use of a flipped classroom in ophthalmology courses for nursing, dental and medical students: A quasi-experimental study using a mixed-methods approach. Nurse Education Today, 104262. doi:10.1016/j.nedt.2019.104262

68. Zimmerman, D. W. (1987). Comparative power of Student t test and Mann-Whitney U test for unequal sample sizes and variances. The Journal of Experimental Education, 55(3), 171-1 